\title{
High-risk Cutaneous Squamous Cell Carcinoma
}

\author{
${ }^{1} \mathrm{C}$ Fitzgerald, 2James Paul O'Neill
}

\begin{abstract}
Cutaneous squamous cell carcinoma (cSCC) is the second most common nonmelanoma skin cancer worldwide. Cutaneous squamous cell carcinoma can potentially be treated fully with minimal morbidity when detected early; however, certain subtypes of cSCC have been shown to confer a poorer prognosis for patients. In these high-risk tumors, increased incidence of recurrence, as well as metastasis to local lymph nodes and distant sites, is seen as a result of certain patient characteristics and pathological features. While guidelines regarding the management of high-risk cSCC have been produced, no clear consensus management or prognostic algorithms exist. In this review, we discuss current definitions of high-risk $\mathrm{CSCC}$, recommendations regarding the management of CSCC, and current guidelines.
\end{abstract}

Keywords: Clinical guidelines, High-risk, Oncology, Squamous cell carcinoma.

How to cite this article: Fitzgerald C, O'Neill JP. High-risk Cutaneous Squamous Cell Carcinoma. Int J Head Neck Surg 2017;8(2):37-44.

\section{Source of support: Nil}

Conflict of interest: None

\section{INTRODUCTION}

Cutaneous squamous cell carcinoma (cSCC) is the second most common nonmelanoma skin cancer worldwide. ${ }^{1,2}$ Risk factors including ultraviolet radiation, fair skin, chronic wounds/scar, ionizing radiation, and certain genetic conditions are well established. ${ }^{1}$ Meanwhile, other factors including human papillomavirus infection have more recently been implicated in certain cases, e.g., in immunosuppressed patients. ${ }^{3}$ The role of a number of genes including TP53, HRAS, EGFR, CDKN2A, and others has also been investigated. ${ }^{4}$

Cutaneous squamous cell carcinoma can potentially be treated fully with minimal morbidity when detected at an early stage; however, certain subtypes of cSCC have been shown to confer a poorer prognosis for patients. ${ }^{5,6}$ In these "high-risk" tumors, increased incidence of

\footnotetext{
${ }^{1}$ Specialist Registrar, ${ }^{2}$ Professor

${ }^{1}$ Department of Otolaryngology, Head \& Neck Surgery, Beaumont Hospital, Dublin, Ireland

${ }^{2}$ Department of Otolaryngology, Head \& Neck Surgery, Royal College of Surgeons in Ireland, Dublin, Ireland

Corresponding Author: James Paul O'Neill, Professor Department of Otolaryngology, Head \& Neck Surgery, Royal College of Surgeons in Ireland, Dublin, Ireland, e-mail: conall. fitzgerald@gmail.com
}

recurrence $(>5 \%)$, as well as metastasis to local lymph nodes and distant sites, is seen as a result of certain patient characteristics and pathological features. 5,7

While the American Joint Committee on Cancer (AJCC) and the National Comprehensive Cancer Network (NCCN) have produced staging systems for cSCC, no clear consensus management or prognostic algorithms exist. ${ }^{8-10}$ In this review, we discuss current definitions of high-risk cSCC, recommendations regarding the management of these cases, and current guidelines.

\section{HIGH-RISK FEATURES IN CSCC}

\section{Defining High-risk Features}

Identifying the small subgroup of cSCCs associated with poor prognosis represents a significant challenge. A number of staging systems, including the AJCC, Union for International Cancer Control, NCCN, and Brigham and Women's Hospital staging systems, are available for CSCC. $^{10-12}$ Both the AJCC and NCCN staging systems define high-risk features of CSCC; however, a number of differences exist between the two (Tables 1 and 2). ${ }^{10,12}$ Notable disparities between the two systems include the exclusion of clinical risk factors, such as recurrence and immunosuppression from AJCC guidelines. Furthermore, AJCC guidelines do not include incomplete excision or lymphovascular invasion as a pathological features denoting high-risk status. In the latest eighth edition of AJCC guidelines, a separate staging for cSCC located in the head and neck has been introduced. ${ }^{13}$

Area $\mathrm{H}$ refers to areas at high risk for recurrence, including mask areas of the face (central face, eyelids, eyebrows, periorbital area, nose, lips, chin, ears, genitalia, hands, and feet). Area $\mathrm{M}$ refers to middle-risk areas for recurrence, including cheeks, forehead, neck, and scalp. Area L refers to low-risk areas for recurrence, including the trunk and extremities.

Table 1: American joint committee on cancer guideline "high-risk" features

Depth
- Breslow's thickness $\geq 2 \mathrm{~mm}$
- Clark level $\geq \mathrm{IV}$
Location
- Ear
- Hair-bearing lip
Poor histological differentiation
Perineural invasion


Table 2: National comprehensive cancer network guideline "high-risk" features

History and presentation:
Location
$-\geq 20 \mathrm{~mm}$ on area $\mathrm{L}$
$-\geq 10 \mathrm{~mm}$ on area $\mathrm{M}$
$-\geq 6 \mathrm{~mm}$ on area $\mathrm{H}$
Poorly defined borders
Site of prior radiotherapy or chronic inflammatory process
Immunosuppression
Recurrent tumor
Rapidly growing tumor
Neurological symptoms
Pathology
Moderate or poor histological differentiation
Adenoid, adenosquamous, desmoplastic, metaplastic subtypes
Depth
- Modified Breslow thickness $\geq 4$ mm
- Clark levels IV or $\mathrm{V}$
Perineural, lymphatic, or vascular invasion

Adapted from the 2016 NCCN Guidelines. ${ }^{10}$ The presence of one of the above factors signifies high risk; Area $\mathrm{H}$ refers to areas at high risk for recurrence, including mask areas of the face (central face, eyelids, eyebrows, periorbital area, nose, lips, chin, ears, genitalia, hands, and feet). Area M refers to middle-risk areas for recurrence, including cheeks, forehead, neck, and scalp. Area $\mathrm{L}$ refers to low-risk areas for recurrence, including the trunk and extremities.

Variations in high-risk features between the two systems may lead to differing classification of the same tumor. For example, Chu et a $1^{14}$ found when retrospectively applying each staging system to 269 cases of cSCC that NCCN categorized $87 \%$ as high risk, while the AJCC conferred a T2, high-risk classification in only $13.9 \%$ of cases, with most of these based on size $2 \mathrm{~cm}$ alone. The inclusion of patient characteristics appeared to lead to a higher proportion of high-risk cases when using NCCN guidelines. The finding of the Brigham and Women's group that a cohort of T2 CSCC could be divided into two groups with distinct prognosis, with the amalgamation of the T3 and T4 stages into a single group, led to the development of a separate tumor staging system for $\mathrm{CSCC}^{11,15}$

Understanding the differences between these staging systems and the relative merits of each is required for clinicians when interpreting definitions of high-risk CSCC.

\section{High-risk Pathological Features}

Consensus regarding the high-risk features of CSCC may guide clinicians in decision-making and may improve prognostic information available for patients. We will now explore in more detail the evidence behind each of the commonly described high-risk features of cSCC.

Tumor size, as a pathological high-risk feature of cSCC, is measured as the maximum diameter of the tumor at excision. Diameter $2 \mathrm{~cm}$ is associated with an increased likelihood of metastasis. ${ }^{5,16}$ The large systematic review and meta-analysis of Thompson et $\mathrm{al}^{17}$ including 17,248 patients highlighted tumor size $2 \mathrm{~cm}$ as a factor associated with local recurrence and metastasis of cSCC [relative risk (RR) 9.64; 95\% confidence interval (CI), 1.30-71.52]. Tumor size $2 \mathrm{~cm}$ is shown to independently predict recurrence and metastasis in multivariate analysis. ${ }^{5}$ Meanwhile, tumor size $2 \mathrm{~cm}$ of the lip or ear has been described by Row et $\mathrm{al}^{18}$ as approximately twice as likely to locally recur (15.2 vs 7.4\%) and three times as likely to metastasize (30.3 vs 9.1\%).

Depth of invasion, or tumor thickness, independently predicts both metastasis and local recurrence and should be measured to the granular layer, to the deepest point of invasion. Both the AJCC and NCCN guidelines include depth of $2 \mathrm{~mm}$ or Clark level IV as a high-risk factor. ${ }^{10,12}$ One large retrospective study of $594 \mathrm{cSCCs}$ found no metastases in the 233 tumors $<2 \mathrm{~mm}$ thick over a median 5.3-year follow-up; $4.7 \%$ (13) of the tumors $>2 \mathrm{~mm}$ but $<5 \mathrm{~mm}$ were shown to metastasize, while $20 \%$ (18) of the 89 tumors $>5 \mathrm{~mm}$ did so. ${ }^{19}$ The prospective study of Brantsch et $\mathrm{l}^{5}$ including 653 patients showed no metastases in patients with cSCC $<2 \mathrm{~mm}$ thickness, but $4 \%$ in tumor thickness $2.1 \mathrm{~mm}$ to $6.0 \mathrm{~mm}$ and $16 \%$ in tumor thickness $>6 \mathrm{~mm}$.

Recurrence of CSCC can be considered an independent high-risk feature of this disease. When compared with primary CSCC, recurrence of tumor at a previous site may be associated with increased size, greater patterns of invasion (lymphovascular and perineural), and nodal spread. ${ }^{20-22}$ Metastasis rates of 32 to $45 \%$ have been highlighted in reviews of recurrent cSCCs of the pinna and lip. ${ }^{18}$

As highlighted, tumor recurrence has, to date, been omitted as a high-risk feature from the AJCC guideline for CSCC, potentially meaning that these tumors are not appropriately upstaged. ${ }^{12}$ Proposals to designate these cases with the letter " $\mathrm{r}$ " when recording tumor characteristics have been supported by a number of authors. ${ }^{14,23}$

Poor histological differentiation has been associated with increased metastasis rates and mortality. Moderate and poor differentiation is included as a high-risk pathological feature in both NCCN and AJCC guidelines. ${ }^{10,12}$ Brinkman et al ${ }^{24}$ previously highlighted metastasis-free survival and overall survival at 5 years are increased in the well-differentiated tumors, when compared with moderately and poorly differentiated lesions, at 70, 51, and $26 \%$ respectively. ${ }^{24}$

Specific histopathological subtypes are also identified as high-risk features in NCCN guidelines, including acantholytic, adenosquamous, desmoplastic, and basosquamous subtypes. ${ }^{25-31}$ Invasive Bowen's disease has 
also been highlighted as a poorly recognized pathology which portends poor outcomes. ${ }^{32}$ Desmoplastic tumors, in particular, have been shown to carry higher risk of metastasis, with Breuninger et al highlighting 6 times more metastases and 10 times more recurrences where desmoplastic subtypes were identified in a sample of 509 patients with cSCC. ${ }^{19}$ To date, these histological details have not been included in AJCC guidelines.

Perineural and lymphovascular invasion have both been highlighted as risk factors for nodal spread of disease in cSCC. ${ }^{7,16,17,33}$ In perineural invasion (PNI), spread of tumor along nerve sheath connective tissue surrounding the fascicles leads to neurological symptoms and pain, which signal spread of disease. ${ }^{34}$ The presence of PNI has been shown to independently predict local recurrence and metastasis in a number of studies, including Thompson's meta-analysis (RR 2.95; 95\% CI $2.31-3.75) .{ }^{17,34,35}$ The association with large-caliber nerves, location on the head and neck, and tumor size, however, have been disputed by some authors. ${ }^{36}$ Similarly, invasion of vascular and lymphatic structures increases the risk of disease spread. ${ }^{5,17}$ Lymphovascular invasion has been recorded as an independent predictor of lymph node metastasis (odds ratio 7.54, $\mathrm{p}<0.0001$ ). ${ }^{7}$ While both AJCC and NCCN guidelines highlight PNI as a high-risk feature, lymphovascular invasion is included only in the NCCN system.

Particular anatomic sites, including the lips, cheeks, forehead, ears, periauricular area, and scalp, have been highlighted as high-risk regions for local recurrence or metastatic spread of $\mathrm{CSCC}$, in particular to parotid and cervical nodes. ${ }^{10,18,37-39}$ In a series of 152 patients with parotid and cervical nodal metastasis, primary tumor sites were cheek $(21.7 \%)$, periauricular area $(20.4 \%)$, temple (15.8\%), and forehead (15.8\%). ${ }^{39}$ The AJCC guidelines classify only the hair-bearing lip and ears as highrisk regions for cSCC. ${ }^{12}$ Meanwhile, NCCN guidelines designate the entire head and neck region as high risk. ${ }^{10}$ Notably, recent meta-analysis has found no independent predicted association between CSCC of the lips and ears with recurrence, in contrast with previous studies. 17,40

Immunosuppression is associated with higher rates of cSCC. ${ }^{41,42}$ Solid organ transplant recipients, such as renal transplant patients, demonstrate a 100 -fold increased risk for invasive cSCC compared with the general population. ${ }^{41}$ Patients transplanted at an older age with a prior history of sun damage or with longer duration or greater intensity of immunosuppression may be at greater risk of developing cSCC. ${ }^{43}$ Immunosuppression with azathioprine or calcineurin inhibitors is closely associated. ${ }^{41,44}$ Unlike the NCCN guideline, the AJCC does not include immunosuppression as a high-risk feature of patients presenting with cSCC. ${ }^{10,12}$
Incomplete excision of surgical margins is not currently recognized as a high-risk feature of cSCC. ${ }^{10,12}$ Rates of incomplete excision range from 5 to $17.6 \%$, with a particular association with high-risk areas of the head and neck. ${ }^{45-49}$ Positive findings on reexcision of incompletely excised cSCC have been associated with a 10 -fold increased risk of recurrence when compared with negative reexcision margins in a 5-year prospective study from Bovill et al. ${ }^{49}$

\section{MANAGEMENT OF HIGH-RISK cSCC}

\section{Parotid Metastases}

In 2002, $\mathrm{O}^{\prime}$ Brien et $\mathrm{al}^{50}$ proposed a staging system to further stratify patients diagnosed with parotid or cervical metastases from cSCC in the head and neck (Table 3). The staging system was based on a prospective study of 87 patients with metastatic cSCC. ${ }^{50}$ P2 and P3 categories in their model were independently associated with decreased disease control in the parotid region. ${ }^{50}$ Meanwhile, N2 designation for the neck was associated with reduced survival. ${ }^{50}$

Later studies led to the development of the N1S3 system, which allowed further staging based on the number and size of any involved nodes in the parotid or neck. ${ }^{51}$ The N1S3 classification demonstrated superior patient stratification when compared with the AJCC TNM staging at later review. ${ }^{51}$

\section{RADIOLOGY}

The presence of high-risk features during clinical evaluation should alert surgeons to the potential for nodal involvement in the neck. Ultrasound may be used as an initial investigation, with additional screening with computed tomography (CT) or magnetic resonance imaging (MRI) or positron emission tomography (PET)$\mathrm{CT}$ as required on a case-by-case basis. While MRI may

Table 3: O’Brien P/N staging system

\begin{tabular}{|c|c|}
\hline \multicolumn{2}{|c|}{ Parotid } \\
\hline P1 & Metastatic node $\leq 3 \mathrm{~cm}$ diameter \\
\hline $\mathrm{P} 2$ & $\begin{array}{l}\text { Metastatic node } \geq 3 \text { and } \leq 6 \mathrm{~cm} \text { diameter or multiple } \\
\text { parotid node }\end{array}$ \\
\hline P3 & $\begin{array}{l}\text { Metastatic node }>6 \mathrm{~cm} \text { diameter or disease involving } \\
\text { cranial nerve VII or skull base }\end{array}$ \\
\hline \multicolumn{2}{|c|}{ Neck } \\
\hline NO & No clinical neck disease \\
\hline N1 & Single ipsilateral neck node $\leq 3 \mathrm{~cm}$ diameter \\
\hline N2 & $\begin{array}{l}\text { Single node }>3 \mathrm{~cm} \text { diameter or multiple neck nodes } \\
\text { or contralateral nodes }\end{array}$ \\
\hline \multicolumn{2}{|c|}{ N1S3 system: } \\
\hline \multicolumn{2}{|c|}{ I) single lymph node $\leq 3 \mathrm{~cm}$} \\
\hline \multicolumn{2}{|c|}{$\begin{array}{l}\text { II) multiple lymph nodes or single lymph node } \geq 3 \mathrm{~cm} \\
\text { III) multiple nodes diameter }>3 \mathrm{~cm}\end{array}$} \\
\hline
\end{tabular}


be recommended in patients with neurological involvement suggestive of PNI, no clear guidelines are currently in place. $^{52}$

\section{SURGERY}

\section{Conventional Surgical Excision}

Radial excision of margins of $4 \mathrm{~mm}$ in low-risk and $6 \mathrm{~mm}$ in high-risk cSCC provides oncologic clearance rates of $95 \%{ }^{53,54}$ European consensus recommendations of $10 \mathrm{~mm}$ in high-risk disease have also been proposed. ${ }^{55}$ Caution should be applied to ensure that the deep excision margin extends to the hypodermis, macroscopically deep to tumor, as the majority of positive margins occur at the deep margin. ${ }^{48,55}$ Where possible neural structures, for example, perichondrium or periostium, should not be disturbed. ${ }^{48}$ Neck dissection should be performed in cases of cervical nodal involvement, with priority given to dissection of levels I and II, where the majority of metastases occur. ${ }^{56}$

\section{Sentinel Lymph Node Biopsy}

Sentinel lymph node biopsy (SLNB) has been well investigated as a means to confirm the presence of subclinical nodal metastasis in melanoma and breast cancer. ${ }^{57-59}$ Its role in the management of cSCC of the head and neck remains opaque. ${ }^{60}$ In the case of melanoma, while sensitivity of 87.5 to $89.2 \%$ has been reported in meta-analysis and prospective trials respectively, data supporting its effect on survival outcomes are lacking. ${ }^{59}$

Limited studies exist to suggest a clear role for SLNB in cSCC. One review of 173 patients with high-risk cSCC undergoing SLNB highlighted 79\% sensitivity and 100\% specificity, with negative predictive value of $96 \%{ }^{61}$ Further systematic reviews have suggested the putative role for SLNB in cSCC may be limited to T2 lesions $>2 \mathrm{~cm}$ diameter lesion only. ${ }^{62}$ Traditionally, the complex drainage pattern of the neck and relatively small nodal size in the neck has led authors to suggest that the procedure is impractical in cSCC. ${ }^{63}$ Further investigation with larger cohorts is required to further guide surgeons.

\section{Elective Neck Dissection}

The use of elective neck dissection in the clinically N0 neck to reveal occult nodal metastases has been reported. ${ }^{64-67}$ To date, however, no prospective study has demonstrated a survival benefit where elective neck dissection is added to management of high-risk cSCC of the head and neck in the N0 setting. ${ }^{67}$ Studies report rates of occult nodal metastasis of 10 to $60 \%$. $^{50,68}$

The Wong and Morton ${ }^{65}$ decision analysis tree for the use of elective neck dissection in the high-risk cSCC with an N0 neck was introduced in 2014. The tool attempts to establish the relative utility of elective neck dissection vs elective nodal irradiation vs surveillance. The decision tree provides a useful framework, but data to support its use are not robust.

\section{Prophylactic Parotidectomy}

The propensity of high-risk cSCC of the head and neck to metastasize to the parotid gland is well established. Veness et $\mathrm{al}^{69}$ have reported 266 cases of metastatic cSCC, with 162 (61\%) involving the parotid gland. On this basis, authors have suggested parotidectomy in cases of T3 or T4 lesions with high-risk features. ${ }^{69}$ Kadakia et al ${ }^{70}$ have retrospectively reported 104 patients following elective parotidectomy for high-risk cSCC of the ear $>2 \mathrm{~cm}$ (without preoperative nodal metastases on radiology). ${ }^{70}$ In total, 39 (37.5\%) demonstrated metastatic cSCC in parotidectomy specimens. ${ }^{70}$ Despite these reports, further studies are required to clarify the precise role of elective parotidectomy for high-risk cSCC.

\section{Mohs Microsurgery}

Mohs microsurgery (MMS) offers a tissue-sparing procedure for cSCC occurring in cosmetically sensitive areas, such as the eye, ear, nose, and lip. ${ }^{71-73}$ Tissue is excised and examined intraoperatively as frozen section to confirm clear margins and limit unnecessary further resection. ${ }^{71,72}$ The systematic review of Lansbury et $\mathrm{al}^{74}$ reports pooled estimate of local recurrence during variable follow-up periods after MMS from 10 studies was $3.0 \%$ (2.2 to $3.9 \%)$, which was nonsignificantly lower than the pooled average local recurrence of 5.4\% (2.5-9.1\%) after standard surgical excision (12 studies), and 6.4\% (3.0-11.0\%) after external radiotherapy (7 studies). ${ }^{74}$ When considered alongside the additional resource burden of the technique, some critics suggest little benefit is offered by MMS, with MMS procedures in the United States costing over $\$ 2$ billion in 2013. ${ }^{75}$

\section{Radiotherapy}

Radiotherapy (RT) may be proposed as adjuvant treatment for high-risk cSCC or as a nonsurgical primary treatment in select candidates. Primary RT has been reported to offer similar cure rates to primary surgery for smaller, low-risk cSCC, but may also be considered in elderly patients or those with significant comorbidities. ${ }^{76,77}$ Adjuvant RT is proposed for advanced primary lesions (T3, T4), in the setting of recurrence and in node-positive disease. ${ }^{35,78}$ Radiotherapy should also be considered in the setting of incomplete excision margins or where PNI is recorded. ${ }^{36}$ It is not clear which patient subgroups would benefit most from adjuvant RT. One 
study of 217 patients with SCC lip highlighted 5-year relapse-free survival of $92 \%$, vs $51 \%$ after surgery alone. ${ }^{79}$ The evidence for adjuvant RT is not supported by randomized trials, however, but rather based on retrospective series, which is acknowledged by NCCN guidelines. $^{10}$

\section{Chemotherapy}

No gold standard chemotherapeutic regimen exists for advanced CSCC, due to the typically limited response of available agents. ${ }^{80,81}$ Relatively nonselective, platinumbased therapies, most commonly with cisplatin with or without 5-fluorouracil, remain the most common chemotherapeutic treatment. ${ }^{80}$ Adjuvant systemic treatment in the form of chemotherapy is typically offered where cSCC lesions have metastasized or have advanced locally beyond a point where surgical resection is possible. Experimental trial of cisplatin in combination with bleomycin and 5-fluorouracil to produce tumor regression permitting surgery has been reported in 11 patients. ${ }^{82}$ Results from randomized trials comparing chemotherapy vs adjuvant RT alone in high-risk cSCC are awaited. Further prospective clinical trials are also required to clarify the role of chemotherapy in highrisk CSCC.

\section{Novel Treatments}

A number of novel treatments in the setting of cutaneous malignancy, including cSCC, have emerged in recent years. Electronic brachytherapy (EBT) allows application of a localized radiation dose through an electrically generated X-ray source on the skin surface. ${ }^{83}$ By allowing for a reduced dosage scatter and small penumbra, EBT can deliver a relatively high dose of treatment in a 2 to 3 minutes period. ${ }^{83,84}$ Bhatnagar et al $^{85}$ reported their experience of 171 nonmelanoma skin lesions, including 70 SCCs, treated with 40 Gy dosage (5 Gy twice a week), with $100 \%$ control at 1-year follow-up. ${ }^{85}$ Limitations of the treatment include its complications, such as rash dermatitis, pruritus, hypopigmentation, and others, as well as limitations in its use for patients with collagen vascular disease, uncontrolled diabetes mellitus, and certain other conditions. ${ }^{85}$

Targeted therapies and forms of immunotherapy utilize the overexpression of epidermal growth factor receptor (EGFR) in the setting of cSCC to disrupt cell proliferation. ${ }^{86-88}$ These novel treatments, which include monoclonal antibodies, such as cetuximab, can offer an overall disease control rate of $69 \%$, as seen in a phase II trial using cetuximab in the setting of metastatic cSCC. ${ }^{88}$ A further stage III randomized trial adding cetuximab to cisplatin significantly improved treatment response when compared with placebo (26.3 vs 9.8\%; $\mathrm{p}=0.29) .{ }^{89}$ The promising human immunoglobulin $\mathrm{G}-2$ monoclonal antibody against EGFR, panitumumab, demonstrated a $31 \%$ response rate in a phase II study of 16 patients with recurrent or metastatic SCC. ${ }^{90}$ In a larger phase III with 51 patients, however, only a $4 \%$ response was recorded. To date, only cetuximab has been granted FDA approval.

The use of immunotherapies, such as programmed cell death protein 1 inhibitors (e.g., nivolumab and pembrolizumab) and the cytolytic T-lymphocyte-associated antigen 4 inhibitors (e.g., ipilimumab), has also been investigated. ${ }^{91-93}$ Early data from the use of these treatments in other malignancies, such as melanoma and SCC of the head and neck suggest that potential response may be seen in cSCC in future. ${ }^{94}$

\section{CONCLUSION}

A high-risk cSCC is a tumor with additional cytological, histopathological, and clinical implications which portend to a worse prognosis. Cutaneous SCC remains a common condition, with an increasing incidence, which is curable if detected and treated at an early stage. Surgical excision with adequate margins, either with MMS or conventional wide radial excision, remains the mainstay of treatment. Controversy exists regarding the role of SLNB, prophylactic parotidectomy, and elective neck dissection in the treatment algorithm. Consensus regarding definitions of high-risk features of cSCC may help guide clinicians in their decision-making and allow clearer prognostic information to be delivered to the patient. Novel therapies, including EBT, immunotherapy, and targeted therapies, may offer an alternative to adjuvant RT and traditional platinum-based chemotherapy where used. It is essential that all clinicians dealing with cSCC have an understanding of the high-risk features. Significant further large, prospective clinical trials will facilitate better understanding of this varied pathology.

\section{REFERENCES}

1. Alam M, Ratner D. Cutaneous squamous-cell carcinoma. N Engl J Med 2001 Mar;344(13): 975-983.

2. Rogers HW, Weinstock MA, Feldman SR, Coldiron BM. Incidence estimate of nonmelanoma skin cancer (keratinocyte carcinomas) in the U.S. population, 2012. JAMA Dermatol 2015 Oct;151(10):1081-1086.

3. Shterzer N, Heyman D, Shapiro B, Yaniv A, Jackman A, Serour F, Chaouat M, Gonen P, Tommasino M, Sherman L. Human papillomavirus types detected in skin warts and cancer differ in their transforming properties but commonly counteract UVB induced protective responses in human keratinocytes. Virology 2014 Nov;468-470:647-659.

4. Lee CS, Bhaduri A, Mah A, Johnson WL, Ungewickell A, Aros CJ, Nguyen CB, Rios EJ, Siprashvili Z, Straight A, et al. 
Recurrent point mutations in the kinetochore gene KNSTRN in cutaneous squamous cell carcinoma. Nat Genet 2014 Oct;46(10):1060-1062.

5. Brantsch KD, Meisner C, Schönfisch B, Trilling B, WehnerCaroli J, Röcken M, Breuninger $\mathrm{H}$. Analysis of risk factors determining prognosis of cutaneous squamous-cell carcinoma: a prospective study. Lancet Oncol 2008 Aug;9(8):713-720.

6. Veness MJ, Palme CE, Morgan GJ. High-risk cutaneous squamous cell carcinoma of the head and neck: results from 266 treated patients with metastatic lymph node disease. Cancer 2006 Jun;106(11):2389-2396.

7. Moore BA, Weber RS, Prieto V, El-Naggar A, Holsinger FC, Zhou X, Lee JJ, Lippman S, Clayman GL. Lymph node metastases from cutaneous squamous cell carcinoma of the head and neck. Laryngoscope 2005 Sep;115(9):1561-1567.

8. Jennings L, Schmults CD. Management of high-risk cutaneous squamous cell carcinoma. J Clin Aesthet Dermatol 2010 Apr;3(4):39-48.

9. Farasat S, Yu SS, Neel VA, Nehal KS, Lardaro T, Mihm MC, Byrd DR, Balch CM, Califano JA, Chuang AY, et al. A new American Joint Committee on Cancer staging system for cutaneous squamous cell carcinoma: creation and rationale for inclusion of tumor $(\mathrm{T})$ characteristics. J Am Acad Dermatol 2011 Jun;64(6):1051-1059.

10. Bichakjian C. NCCN Clinical Practice Guidelines in Oncology (NCCN Guidelines) Squamous Cell Skin Cancer. National Comprehensive Cancer Network, 2016.

11. Jambusaria-Pahlajani A, Kanetsky PA, Karia PS, Hwang WT, Gelfand JM, Whalen FM, Elenitsas R, Xu X, Schmults CD. Evaluation of AJCC tumor staging for cutaneous squamous cell carcinoma and a proposed alternative tumor staging system. JAMA Dermatol 2013 Apr;149(4):402-410.

12. AJCC. AJCC Cancer Staging Manual. 7th ed. 2010.

13. AJCC. AJCC Cancer Staging Manual. 8th ed. 2016.

14. Chu MB, Slutsky JB, Dhandha MM, Beal BT, Armbrecht ES, Walker RJ, Varvares MA, Fosko SW. Evaluation of the definitions of "high-risk" cutaneous squamous cell carcinoma using the American Joint Committee on cancer staging criteria and national comprehensive cancer network guidelines. J Skin Cancer 2014;2014:154340.

15. Karia PS, Jambusaria-Pahlajani A, Harrington DP, Murphy GF, Qureshi AA, Schmults CD. Evaluation of American Joint Committee on Cancer, International Union Against Cancer, and Brigham and Women's Hospital tumor staging for cutaneous squamous cell carcinoma. J Clin Oncol 2014 Feb 1;32(4):327-334.

16. Cherpelis BS, Marcusen C, Lang PG. Prognostic factors for metastasis in squamous cell carcinoma of the skin. Dermatol Surg 2002 Mar;28(3):268-273.

17. Thompson AK, Kelley BF, Prokop LJ, Murad MH, Baum CL. Risk factors for cutaneous squamous cell carcinoma recurrence, metastasis, and disease-specific death: A systematic review and meta-analysis. JAMA Dermatol 2016 Apr;152(4): 419-428.

18. Rowe DE, Carroll RJ, Day CL Jr. Prognostic factors for local recurrence, metastasis, and survival rates in squamous cell carcinoma of the skin, ear, and lip. Implications for treatment modality selection. J Am Acad Dermatol 1992 Jun;26(6): 976-990.

19. Breuninger H, Schaumburg-Lever G, Holzschuh J, Horny HP. Desmoplastic squamous cell carcinoma of skin and vermilion surface: a highly malignant subtype of skin cancer. Cancer 1997 Mar;79(5):915-919.
20. Clayman GL, Lee JJ, Holsinger FC, Zhou X, Duvic M, El-Naggar AK, Prieto VG, Altamirano E, Tucker SL, Strom SS, et al. Mortality risk from squamous cell skin cancer. J Clin Oncol 2005 Feb;23(4):759-765.

21. Peat $B$, Insull $P$, Ayers R. Risk stratification for metastasis from cutaneous squamous cell carcinoma of the head and neck. ANZ J Surg 2012 Apr;82(4):230-233.

22. Mourouzis C, Boynton A, Grant J, Umar T, Wilson A, Macpheson D, Pratt C. Cutaneous head and neck SCCs and risk of nodal metastasis - UK experience. J Craniomaxillofac Surg 2009 Dec;37(8):443-447.

23. Dinehart SM, Peterson S. Evaluation of the American Joint Committee on cancer staging system for cutaneous squamous cell carcinoma and proposal of a new staging system. Dermatol Surg 2005;31(11 Pt 1):1379-1384.

24. Brinkman JN, Hajder E, van der Holt B, Den Bakker MA, Hovius SE, Mureau MA. The effect of differentiation grade of cutaneous squamous cell carcinoma on excision margins, local recurrence, metastasis, and patient survival: A retrospective follow-up study. Ann Plast Surg 2015 Sep;75(3):323-326.

25. Wermker K, Roknic N, Goessling K, Klein M, Schulze HJ, Hallermann C. Basosquamous carcinoma of the head and neck: clinical and histologic characteristics and their impact on disease progression. Neoplasia 2015 Mar;17(3):301-305.

26. Sajin M, Hodorogea Prisăcaru A, Luchian MC, Pătraşcu OM, Dumitru A, Costache D, Dumitrescu D, Vrînceanu D, Voinea LM, Simionescu O, et al. Acantholytic squamous cell carcinoma: pathological study of nine cases with review of literature. Rom J Morphol Embryol 2014;55(2):279-283.

27. Breuninger $H$, Holzschuh J, Schaumburg Lever G, Schippert W, Horny HP. [Desmoplastic squamous epithelial carcinoma of the skin and lower lip. A morphologic entity with great risk of metastasis and recurrence]. Hautarzt 1998 Feb;49(2):104-108.

28. Petter G, Haustein UF. Squamous cell carcinoma of the skin histopathological features and their significance for the clinical outcome. J Eur Acad Dermatol Venereol 1998 Jul;11(1):37-44.

29. O'Shea C, Fitzpatrick JE, Koch PJ. Desmosomal defects in acantholytic squamous cell carcinomas. J Cutan Pathol 2014 Nov;41(11):873-879.

30. Banks ER, Cooper PH. Adenosquamous carcinoma of the skin: a report of 10 cases. J Cutan Pathol 1991 Aug;18(4):227-234.

31. Kececi Y, Argon A, Kebat T, Sir E, Gungor M, Vardar E. Basosquamous carcinoma: is it an aggressive tumor? J Plast Surg Hand Surg 2015 Apr;49(2):107-111.

32. Kao GF. Carcinoma arising in Bowen's disease. Arch Dermatol 1986 Oct;122(10):1124-1126.

33. Fagan JJ, Collins B, Barnes L, D'Amico F, Myers EN, Johnson JT. Perineural invasion in squamous cell carcinoma of the head and neck. Arch Otolaryngol Head Neck Surg 1998 Jun;124(6): 637-640.

34. Garcia-Serra A, Hinerman RW, Mendenhall WM, Amdur RJ, Morris CG, Williams LS, Mancuso AA. Carcinoma of the skin with perineural invasion. Head Neck 2003 Dec;25(12): 1027-1033.

35. Jambusaria-Pahlajani A, Miller CJ, Quon H, Smith N, Klein RQ, Schmults CD. Surgical monotherapy versus surgery plus adjuvant radiotherapy in high-risk cutaneous squamous cell carcinoma: a systematic review of outcomes. Dermatol Surg 2009 Apr;35(4):574-585.

36. Ross AS, Whalen FM, Elenitsas $R, X u X$, Troxel AB, Schmults CD. Diameter of involved nerves predicts outcomes in cutaneous squamous cell carcinoma with perineural invasion: an 
investigator-blinded retrospective cohort study. Dermatol Surg 2009 Dec;35(12):1859-1866.

37. Brougham ND, Dennett ER, Cameron R, Tan ST. The incidence of metastasis from cutaneous squamous cell carcinoma and the impact of its risk factors. J Surg Oncol 2012 Dec;106(7): 811-815.

38. Clark RR, Soutar DS. Lymph node metastases from auricular squamous cell carcinoma. A systematic review and metaanalysis. J Plast Reconstr Aesthet Surg 2008 Oct;61(10): 1140-1147.

39. Vauterin TJ, Veness MJ, Morgan GJ, Poulsen MG, O’Brien CJ. Patterns of lymph node spread of cutaneous squamous cell carcinoma of the head and neck. Head Neck 2006 Sep;28(9): 785-791.

40. Schmults CD, Karia PS, Carter JB, Han J, Qureshi AA. Factors predictive of recurrence and death from cutaneous squamous cell carcinoma: a 10-year, single-institution cohort study. JAMA Dermatol 2013 May;149(5):541-547.

41. Manyam BV, Gastman B, Zhang AY, Reddy CA, Burkey BB, Scharpf J, Alam DS, Fritz MA, Vidimos AT, Koyfman SA. Inferior outcomes in immunosuppressed patients with highrisk cutaneous squamous cell carcinoma of the head and neck treated with surgery and radiation therapy. J Am Acad Dermatol 2015 Aug;73(2):221-217.

42. Ingvar A, Smedby KE, Lindelöf B, Fernberg P, Bellocco R, Tufveson G, Höglund P, Adami J. Immunosuppressive treatment after solid organ transplantation and risk of posttransplant cutaneous squamous cell carcinoma. Nephrol Dial Transplant 2010 Aug;25(8):2764-2771.

43. (SIGN), S.I.G.N. Management of primary cutaneous squamous cell carcinoma: a national clinical guideline. 2014.

44. Perrett CM, Walker SL, O'Donovan P, Warwick J, Harwood CA, Karran P, McGregor JM. Azathioprine treatment photosensitizes human skin to ultraviolet A radiation. Br J Dermatol 2008 Jul;159(1):198-204.

45. Skulsky SL, O'Sullivan B, McArdle O, Leader M, Roche M, Conlon PJ, O'Neill JP. Review of high-risk features of cutaneous squamous cell carcinoma and discrepancies between the American Joint Committee on Cancer and NCCN Clinical Practice Guidelines in Oncology. Head Neck 2017 Mar;39(3):578-594

46. Mirshams M, Razzaghi M, Noormohammadpour P, Naraghi Z, Kamyab K, Sabouri Rad S. Incidence of incomplete excision in surgically treated cutaneous squamous cell carcinoma and identification of the related risk factors. Acta Med Iran 2011;49(12):806-809.

47. Hansen C, Wilkinson D, Hansen M, Soyer HP. Factors contributing to incomplete excision of nonmelanoma skin cancer by Australian general practitioners. Arch Dermatol 2009 Nov;145(11):1253-1260.

48. Khan AA, Potter M, Cubitt JJ, Khoda BJ, Smith J, Wright EH, Scerri G, Crick A, Cassell OC, Budny PG. Guidelines for the excision of cutaneous squamous cell cancers in the United Kingdom: the best cut is the deepest. J Plast Reconstr Aesthet Surg 2013 Apr;66(4):467-471.

49. Bovill ES, Cullen KW, Barrett W, Banwell PE. Clinical and histological findings in re-excision of incompletely excised cutaneous squamous cell carcinoma. J Plast Reconstr Aesthet Surg 2009 Apr;62(4):457-461.

50. O'Brien CJ, McNeil EB, McMahon JD, Pathak I, Lauer CS, Jackson MA. Significance of clinical stage, extent of surgery, and pathologic findings in metastatic cutaneous squamous carcinoma of the parotid gland. Head Neck 2002 May;24(5):417-422.

51. Forest VI, Clark JJ, Veness MJ, Milross C. N1S3: a revised staging system for head and neck cutaneous squamous cell carcinoma with lymph node metastases: results of 2 Australian Cancer Centers. Cancer 2010 Mar 1;116(5):1298-1304.

52. Williams LS, Mancuso AA, Mendenhall WM. Perineural spread of cutaneous squamous and basal cell carcinoma: CT and MR detection and its impact on patient management and prognosis. Int J Radiat Oncol Biol Phys 2001 Mar;49(4): 1061-1069.

53. Brodland DG, Zitelli JA. Surgical margins for excision of primary cutaneous squamous cell carcinoma. J Am Acad Dermatol 1992 Aug;27(2 Pt 1):241-248.

54. Motley R, Kersey P, Lawrence C; British Association of Dermatologists; British Association of Plastic Surgeons. Multiprofessional guidelines for the management of the patient with primary cutaneous squamous cell carcinoma. Br J Plast Surg 2003 Mar;56(2):85-91.

55. Stratigos A, Garbe C, Lebbe C, Malvehy J, del Marmol V, Pehamberger H, Peris K, Becker JC, Zalaudek I, Saiag P, et al. Diagnosis and treatment of invasive squamous cell carcinoma of the skin: European consensus-based interdisciplinary guideline. Eur J Cancer 2015 Sep;51(14):1989-2007.

56. Chen MM, Roman SA, Sosa JA, Judson BL. Prognostic factors for squamous cell cancer of the parotid gland: an analysis of 2104 patients. Head Neck 2015 Jan;37(1):1-7.

57. Kell MR, Kerin MJ. Sentinel lymph node biopsy. BMJ 2004;328(7452):1330-1331.

58. Lyman GH, Giuliano AE, Somerfield MR, Benson AB 3rd, Bodurka DC, Burstein HJ, Cochran AJ, Cody HS 3rd, Edge SB, Galper S, et al. American Society of Clinical Oncology guideline recommendations for sentinel lymph node biopsy in early-stage breast cancer. J Clin Oncol 2005 Oct;23(30):7703-7720.

59. Morton DL, Thompson JF, Cochran AJ, Mozzillo N, Nieweg OE, Roses DF, Hoekstra HJ, Karakousis CP, Puleo CA, Coventry BJ, et al. Final trial report of sentinel-node biopsy versus nodal observation in melanoma. N Engl J Med 2014 Feb;370(7):599-609.

60. Ahmed MM, Moore BA, Schmalbach CE. Utility of head and neck cutaneous squamous cell carcinoma sentinel node biopsy: a systematic review. Otolaryngol Head Neck Surg 2014 Feb;150(2):180-187.

61. Allen JE, Stolle LB. Utility of sentinel node biopsy in patients with high-risk cutaneous squamous cell carcinoma. Eur J Surg Oncol 2015 Feb;41(2):197-200.

62. Schmitt AR, Brewer JD, Bordeaux JS, Baum CL. Staging for cutaneous squamous cell carcinoma as a predictor of sentinel lymph node biopsy results: meta-analysis of American Joint Committee on Cancer criteria and a proposed alternative system. JAMA Dermatol 2014 Jan;150(1):19-24.

63. Ross AS, Schmults CD. Sentinel lymph node biopsy in cutaneous squamous cell carcinoma: a systematic review of the English literature. Dermatol Surg 2006 Nov;32(11):1309-1321.

64. Peiffer N, Kutz JW Jr, Myers LL, Isaacson B, Sumer BD, Truelson JM, Ahn C, Roland PS. Patterns of regional metastasis in advanced stage cutaneous squamous cell carcinoma of the auricle. Otolaryngol Head Neck Surg 2011 Jan;144(1):36-42.

65. Wong WK, Morton RP. Elective management of cervical and parotid lymph nodes in stage N0 cutaneous squamous cell carcinoma of the head and neck: a decision analysis. Eur Arch Otorhinolaryngol 2014 Nov;271(11):3011-3019. 
66. Kirke DN, Porceddu S, Wallwork BD, Panizza B, Coman WB. Pathologic occult neck disease in patients with metastatic cutaneous squamous cell carcinoma to the parotid. Otolaryngol Head Neck Surg 2011 Apr;144(4):549-551.

67. Dona E, Veness MJ, Cakir B, Morgan GJ. Metastatic cutaneous squamous cell carcinoma to the parotid: the role of surgery and adjuvant radiotherapy to achieve best outcome. ANZ J Surg 2003 Sep;73(9):692-696.

68. Corlette TH, Cole IE, Albsoul N, Ayyash M. Neck dissection of level IIb: is it really necessary? Laryngoscope 2005 Sep;115(9):1624-1626.

69. Veness MJ. High-risk cutaneous squamous cell carcinoma of the head and neck. J Biomed Biotechnol 2007 Apr; 2007(3):80572

70. Kadakia S, Saman M, Gordin E, Marra D, Ducic Y. The role of parotidectomy in the treatment of auricular squamous cell carcinoma. Otolaryngol Head Neck Surg 2015 Jun;152(6): 1048-1052.

71. Leibovitch I, Huilgol SC, Selva D, Hill D, Richards S, Paver R. Cutaneous squamous cell carcinoma treated with Mohs micrographic surgery in Australia I. Experience over 10 years. J Am Acad Dermatol 2005 Aug;53(2):253-260.

72. Belkin D, Carucci JA. Mohs surgery for squamous cell carcinoma. Dermatol Clin 2011;29(2):161-174, vii.

73. Pugliano-Mauro M, Goldman G. Mohs surgery is effective for high-risk cutaneous squamous cell carcinoma. Dermatol Surg 2010 Oct;36(10):1544-1553.

74. Lansbury L, Bath-Hextall F, Perkins W, Stanton W, Leonardi-Bee J. Interventions for non-metastatic squamous cell carcinoma of the skin: systematic review and pooled analysis of observational studies. BMJ 2013 Nov;347:f6153.

75. Chuang GS, Lu LK, Cummins DL, Wu H, Finn D, Rogers GS, Lee D. Incidence of invasive squamous cell carcinomas in biopsy-proven squamous cell carcinomas in situ sent for Mohs micrographic surgery. Dermatol Surg 2012 Jun;38(9): 1456-1460.

76. Caccialanza M, Piccinno R, Gaiani F, Contini D. Relevance of dermatologic radiotherapy in the therapeutic strategy of skin epithelial neoplasms: excellent results in the treatment of lesions localized on eyelids and skin overlying the cartilage of the nose. G Ital Dermatol Venereol 2013 Feb;148(1):83-88.

77. Veness MJ, Ong C, Cakir B, Morgan G. Squamous cell carcinoma of the lip. Patterns of relapse and outcome: Reporting the Westmead Hospital experience, 1980-1997. Australas Radiol 2001;45(2):195-199.

78. Veness MJ. Treatment recommendations in patients diagnosed with high-risk cutaneous squamous cell carcinoma. Australas Radiol 2005 Oct;49(5):365-376.

79. Najim M, Cross S, Gebski V, Palme CE, Morgan GJ, Veness MJ. Early-stage squamous cell carcinoma of the lip: the Australian experience and the benefits of radiotherapy in improving outcome in high-risk patients after resection. Head Neck 2013 Oct;35(10):1426-1430.

80. Jarkowski A 3rd, Hare R, Loud P, Skitzki JJ, Kane JM 3rd, May KS, Zeitouni NC, Nestico J, Vona KL, Groman A, et al.
Systemic therapy in advanced cutaneous squamous cell carcinoma (CSCC): The Roswell Park experience and a review of the literature. Am J Clin Oncol 2016 Dec;39(6):545-548.

81. DeConti RC. Chemotherapy of squamous cell carcinoma of the skin. Semin Oncol 2012 Apr;39(2):145-149.

82. Sadek H, Azli N, Wendling JL, Cvitkovic E, Rahal M, Mamelle G, Guillaume JC, Armand JP, Avril MF. Treatment of advanced squamous cell carcinoma of the skin with cisplatin, 5-fluorouracil, and bleomycin. Cancer 1990 Oct;66(8):1692-1696.

83. Pons-Llanas O, Ballester-Sánchez R, Celada-Álvarez FJ, Candela-Juan C, García-Martínez T, Llavador-Ros M, BotellaEstrada R, Barker CA, Ballesta A, Tormo-Micó A, et al. Clinical implementation of a new electronic brachytherapy system for skin brachytherapy. J Contemp Brachytherapy 2015 Jan;6(4): 417-423.

84. Garcia-Martinez T, Chan JP, Perez-Calatayud J, Ballester F. Dosimetric characteristics of a new unit for electronic skin brachytherapy. J Contemp Brachytherapy 2014 Mar;6(1):45-53

85. Bhatnagar A. Nonmelanoma skin cancer treated with electronic brachytherapy: results at 1 year. Brachytherapy 2013 Mar-Apr;12(2):134-140.

86. Shimizu T, Izumi H, Oga A, Furumoto H, Murakami T, Ofuji R, Muto M, Sasaki K. Epidermal growth factor receptor overexpression and genetic aberrations in metastatic squamous-cell carcinoma of the skin. Dermatology 2001;202(3):203-206.

87. Uribe P, Gonzalez S. Epidermal growth factor receptor (EGFR) and squamous cell carcinoma of the skin: molecular bases for EGFR-targeted therapy. Pathol Res Pract 2011 Jun;207(6):337-342.

88. Gaffney DC, Soyer HP, Simpson F. The epidermal growth factor receptor in squamous cell carcinoma: An emerging drug target. Australas J Dermatol 2014 Feb;55(1):24-34.

89. Burtness B, Goldwasser MA, Flood W, Mattar B, Forastiere AA; Eastern Cooperative Oncology Group. Phase III randomized trial of cisplatin plus placebo compared with cisplatin plus cetuximab in metastatic/recurrent head and neck cancer: an Eastern Cooperative Oncology Group study. J Clin Oncol 2005 Dec;23(34):8646-8654.

90. Foote MC, McGrath M, Guminski A, Hughes BG, Meakin J, Thomson D, Zarate D, Simpson F, Porceddu SV. Phase II study of single-agent panitumumab in patients with incurable cutaneous squamous cell carcinoma. Ann Oncol 2014 Oct;25(10):2047-2052.

91. Honeychurch J, Cheadle EJ, Dovedi SJ, Illidge TM. Immunoregulatory antibodies for the treatment of cancer. Expert Opin Biol Ther 2015 Jun;15(6):787-801.

92. Agarwala SS. Practical Approaches to Immunotherapy in the Clinic. Semin Oncol 2015 Dec;42 (Suppl 3):S20-S27.

93. Lipson EJ, Bodell MA, Kraus ES, Sharfman WH. Successful administration of ipilimumab to two kidney transplantation patients with metastatic melanoma. J Clin Oncol 2014 Jul;32(19):e69-e71.

94. Gildener-Leapman N, Ferris RL, Bauman JE. Promising systemic immunotherapies in head and neck squamous cell carcinoma. Oral Oncol 2013 Dec;49(12):1089-1096. 